Jurnal Keuangan dan Perbankan, Vol.19, No.3 September 2015, hlm. 378-390

Terakreditasi SK. No. 040/P/2014

http://jurkubank.wordpress.com

\title{
PENGARUH MANAJEMEN LABA TERHADAP RASIO KEUANGAN PRODUK INDUSTRI KREATIF KERAMIK
}

\author{
I Nyoman Normal \\ Unit Pelaksana Teknis Pengembangan Seni dan Teknologi Keramik dan Porselin (UPT PSTKP) Bali, \\ Badan Pengkajian dan Penerapan Teknologi (BPPT),
}

\begin{abstract}
s
Theaims of this research is determinetheinfluence of earning management to financial ratio ceramics creative industry product. The research results shew that theearning management that applied by over production can increasefinancial ratio ceramics creativeindustry product, that is: a) The liquidity aspect (quick ratio) 5,33\% for earthenware, 1,00\% for stoneware, $0,67 \%$ for castlemass, 2,00\% for glazur, and 0,33\% for prothotype, b) Theprofitability aspect (profit margin) 2,89\% for earthen ware, 2,31\% for stoneware, $0,18 \%$ for castlemass, $1,65 \%$ for glazur, and $0,41 \%$ for prothotype, c) The solvability aspect (time interest earned) 1,31 times for earthen ware, 1,16 times for stoneware, 0,02 times for castle mass, 0,71 times for glazur, and 0,15 times for prothotype, and d) The valuation aspect (earning peer share) Rp 707,23 for earthen ware, Rp 812,63 for stoneware, Rp 319,12 for castle mass, Rp 44,69 for glazur, and R p 8,21 for prothotipe. Its contrary, the earning management can decr ease activity aspect (turnover inventory) ceramics creative industry product (earthenware, stoneware, castlemass, glazur, and prothotype), theseare 3,8 times, 6,47 times, 5,27 times, 8,11 times, and 11,90 times.
\end{abstract}

Key w ords: earning management, financial ratio, ceramic creativeindustry.

Perusahaan manufaktur di Indoensia merupakan penopang utama perkembangan industri (Rolita, 2014). Peningkatan laju pertumbuhan manufaktur dikarenakan adanya konsumsi domestik yang meningkat tajam dalam beberapa tahun terakhir (Maryam, 2013). Sektor industry manufaktur berkontribusi hingga 20,85\% terhadap produk domestic bruto (PDB) nasional. Manajer sebagai pengelola perusahaan lebih banyak mengetahui informasi internal dan prospek perusahaan di masa yang akan datang dibandingkan pemilik (pemegang saham). Oleh karena itu sebagai pengelola, manajer berkewajiban memberikan sinyal mengenai kondisi perusahaan kepada pemilik (Purwanto, et al, 2012).

Setiap perusahaan pada saat ini sangat memperhatikan hasil laporan keuangan perusahaannya, karena dengan laporan keuangan yang baik dan bisa menghasilkan laba maksimal yang akan dapat

Koresponden dengan Penulis

I Nyoman Normal, Telp: 0361723969 (k), 0361727936 (r), 085792377505 (hp), Fax: 0361723867

E-mail: inyomannormal_s@yahoo.com 


\section{Pengaruh M anajemen Laba terhadap Rasio Keuangan Produk Industri Kreatif Keramik}

I N yoman $\mathrm{N}$ ormal

menarik para investor bergabung untuk menginvestasikan modalnya bagi perusahaan tersebut (Agustina \& A hmar, 2014). Persoal an keagenan timbul karena pemisahan antara pemilik (principal) yang mendelegasikan wewenang kepada manajer (agent) (Sutriasih, et al, 1058). Armando \& Farahmita (2012) berpendapat bahwa untuk meningkatkan laba, manajer perusahaan dapat memproduksi lebih banyak daripada yang diperlukan dengan asumsi bahwa tingkat produksi yang lebih tinggi akan menyebabkan biaya tetap per unit produk lebih rendah. Strategi ini dapat menurunkan biaya barang terjual (cost of goods sold) dan meningkatkan laba operasi. Penetapan harga pokok produk sangatlah penting bagi manajemen untuk menentukan harga jual produk, memantau realisasi biaya produksi, menghiutng laba rugi periodik, menentukan harga pokok persediaan produk jadi dan produk dalam proses yang disajikan dalam neraca Mulyadi dalam A rizona (2014).

Eearning management dapat dilakukan dengan dua cara (A gustina \& A hmar, 2014), yaitu: dengan cara manipulasi akrual dan manajemen laba riil. Metode yang digunakan dalam melakukan manipulasi riil melalui biaya produksi ini adalah produksi berlebih (over production), sehingga biaya overhead tetap dapat dialokasikan pada jumlah unit lebih besar sehingga biaya tetap per unitnya akan lebih rendah dan harga pokok penjualan untuk memproduksi barangpun akan lebih kecil (Roychowdhury, 2006). Secara umum, tujuan suatu perusahaan didirikan adalah menciptakan kekayaan. Untuk mencapai tujuan tersebut, perusahaan harus memiliki produk yang dapat dijual kepada masyarakat (Rudianto, 2013). Keramik merupakan produk yang dibutuhkan oleh manusia sebagai alat rumah tangga, benda seni, alat pelengkap bangunan, dan sebagainya (Normal, 2013:57).

Jasa teknologi yang dihasilkan oleh UPT PSTKP Bali adalah massa gerabah (earthenware), massa keramik batu (stoneware), massa cor (castle mass), glasir (glazur), prototipe (prothotype), dan jasa lainnya. Dalam rangka meningkatkan kinerja, seringkali manajemen menaikkan produksinyauntuk mengisi persediaan dan menurunkan biaya satuan produk. Kenaikan produksi akan membawa dampak terhadap rasio keuangan periodetersebut. PadaTabel 1 ditunjukkan data biaya produksi produk keramik sebelum adanya manajemen laba.

Tabel 1: Biaya Produksi Produk Kreatif Keramik Sebelum Adanya M anajemen Laba (Rp)

\begin{tabular}{|c|c|c|c|c|c|c|}
\hline \multirow{2}{*}{\multicolumn{2}{|c|}{$\begin{array}{l}\text { Produk Kreatif } \\
\text { Keramik }\end{array}$}} & \multicolumn{4}{|c|}{$\begin{array}{c}\text { Elemen } \\
\text { Biaya Produksi }\end{array}$} & \multirow{2}{*}{$\begin{array}{c}\text { H arga Pokok } \\
\text { Produksi }\end{array}$} \\
\hline & & BBB & BT KL & BO PV & BO PT & \\
\hline \multirow{3}{*}{ Earthenware } & BJ N-2 & $1.031,89$ & 282,93 & 77,00 & 389,46 & $1.781,28$ \\
\hline & TR-1 & $1.536,85$ & 238,42 & 71,01 & 407,54 & $2.253,82$ \\
\hline & SGR-1 & $1.274,14$ & 189,38 & 64,33 & 499,78 & $2.027,63$ \\
\hline & B2-B & $1.730,04$ & 348,75 & 97,65 & 415,54 & $2.591,98$ \\
\hline \multirow{3}{*}{ Stoneware } & $B L-1 X$ & $1.688,12$ & 189,38 & 64,33 & 499,78 & $2.441,61$ \\
\hline & BSK -2 & $1.651,52$ & 302,44 & 89,93 & 415,54 & $2.459,43$ \\
\hline & $\mathrm{CN}-7$ & $2.000,00$ & 928,53 & 39,89 & 36,09 & $3.004,52$ \\
\hline \multirow[t]{3}{*}{ M assa Cor } & CN-6 & $1.980,46$ & 989,64 & 39,89 & 37,01 & $3.047,00$ \\
\hline & $\mathrm{CN}-1$ & $1.903,00$ & 917,50 & 39,89 & 37,01 & $2,897,40$ \\
\hline & GHK-3 & $6.586,63$ & $23.415,00$ & $12.208,12$ & $5.333,52$ & $47.543,27$ \\
\hline \multirow[t]{3}{*}{ Glasir } & GM R-1 & $5.820,74$ & $23.415,00$ & $12.511,26$ & $5.184,96$ & $46.931,96$ \\
\hline & GK-1 & $5.448,05$ & $23.415,00$ & $12.511,26$ & $5.184,96$ & $46.559,27$ \\
\hline & Cangkir $\mathrm{H}$ ijau & $7.100,00$ & $22.498,64$ & 834,30 & 630,25 & $31.063,19$ \\
\hline \multirow[t]{2}{*}{ Prototipe } & Teko Coklat & $48.250,00$ & $57.637,19$ & $15.089,42$ & $2.977,47$ & $123.954,08$ \\
\hline & Piring C eper & $23.750,00$ & $17.423,76$ & $10.105,88$ & $1.462,42$ & $52.741,56$ \\
\hline
\end{tabular}

Sumber: UPT PSTKP Bali, 2015. 


\section{Jurnal Keuangan dan Perbankan | KEUANGAN}

Vol. 19, N o.3, September 2015: 378-390

H arga pokok produksi earthenware berkisar antara Rp 1.781,28 s.d Rp 2.253,82 per kg, stoneware Rp 2.421,55 s.d Rp 2.491,98 per kg, massa cor Rp 2,897,40 s.d Rp 3.047,00 per liter, glasir Rp 46.559,27 s.d Rp 47.543,27per liter, dan prototipe keramik Rp 6.355,08 s.d Rp 123.954,08 per buah. Harga pokok produksi merupakan unsur dalam perhitungan rasio keuangan. Variasi harga pokok produksi produk keramik akan menciptakan variasi rasio keuangan. Manajer yang rasional akan menggunakan peluang ini untuk memperbaiki rasio keuangan sehingga dapat meningkatkan kinerja, karena kinerja menjadi ukuran atau kualifikasi bagi seorang manajer untuk memperoleh bonus, insentif, atau bentuk imbalan lainnya.

Permasalahan pada penelitian ini adalah bagaimana pengaruh manajemen laba terhadap rasio keuangan produk keramik. Tujuan penelitian ini adalah ingin mengetahui pengaruh manajemen laba (yang dilakukan dengan pendekatan biaya produksi) terhadap rasio keuangan (likuiditas, profitabilitas, solvabilitas, aktivitas, dan penilaian). Hasil penelitian ini diharapkan bermanfaat bagi: (1) UPT PSTKP Bali dan pengusaha (perajin) keramik, sebagai acuan memberikan pemahaman mengenai alat manipulasi manajemen laba melalui aktivitas riil, (2) bagi investor dan kreditur, sebagai sal ah satu pertimbangan dalam pengambilan keputusan investasi dan pemberian kredit, dan (3) bagi kalangan akademis (fungsional lainnya), sebagai bahan tambahan atau referensi dibidang keuangan untuk menghasilkan penelitian selanjutnya yang lebih baik.

\section{Manajemen Laba}

Schipper dalam Purwanto, et al, (2012) mendefinisikan manajemen laba sebagai suatu intervensi dengan maksud tertentu terhadap proses pelaporan keuangan eksternal dengan sengaja untuk memperoleh beberapa keuntungan pribadi. Sulistiawan, et al. dalam Agustina (2014) menam- bahkan bahwa manajemen laba melalui aktivitas riil menunjuk pada permainan angka laba yang dilakukan dengan melalui aktivitas-aktivitas yang berasal dari kegiatan bisnis normal atau yang berhubungan dengan kegiatan operasional, menunda kegiatan promosi produk atau mempercepat penjualan dengan pemberian diskon besarbesaran. Ratmono dalam A gustina (2014) menyatakan bahwa praktik manajemen laba riil dapat dilakukan dengan menggunakan tiga metode, sebagai berikut: manipulasi penjualan, penurunan beban-beban diskresionari (discretionary expenditures), dan produksi yang berlebihan (overproduction).

Tuanakotta (2013) dalam (http:/ / semangadmu. blogspot.com/ 2013/ 11/ manajemen-laba-apakahtermasuk fraud.html) menyebutkan fraud adalah: (a). Perbuatan melawan hukum, (b). Perbuatan yang mengandung: 1) Unsur kesengajaan, 2) Niat Jahat, 3) Penipuan, 4) Penyembunyian, dan 5) Penyalahgunaan kepercayaan, dan (c). Seorang dikatakan melakukan fraud apabila segala unsur terpenuhi, jika salah satunya cacat atau tidak terpenuhi, tindakan tersebut bukan masuk kategori fraud.

\section{Rasio Keuangan}

Rasio keuangan adalah petunjuk yang menuntun manajemen sebuah perusahaan menetapkan berbagai target serta standar (Wiagustini, 2014). Menurut Kasmir (2014), rasio keuangan merupakan kegiatan membandingkan angka-angka yang ada dalam laporan keuangan dengan cara membagi satu angka dalam laporan keuangan dengan angka lainnya. Angka yang diperbandingkan dapat berupa angka-angka dalam satu periode maupun beberapa periode. Kondisi keuangan dapat dilihat dari bebagai aspek (Wiagustini, 2014), yaitu: likuiditas, solvabilitas (lever age), profitabilitas (rentabilitas), aktivitas usaha, dan penilaian (pasar). 


\section{Pengaruh Manajemen Laba terhadap Rasio Keuangan Produk Industri Kreatif Keramik}

I $\mathrm{N}$ yoman $\mathrm{N}$ ormal

\section{Industri Kreatif Keramik}

Industri kreatif dapat diartikan sebagai kumpulan aktivitas ekonomi yang terkait dengan penciptaan atau penggunaan pengetahuan dan informasi (http:/ id.wikipedia. org/ wiki/ Industri_ kreatif). Sub sektor yang merupakan industry berbasis kreativitas di Indonesia berdasarkan pemetaan industry kreatif yang telah dilakukan oleh Kementerian Perdagangan Republik Indonesia adalah: 1) Periklanan, 2) Arsitektur, 3) Pasar barang seni, 4) Kerajinan, 5) Desain, 6) Fesyen, 7) Video, film, dan fotografi, 8) Permainan interaktif, 9) Musik, 10) Seni pertunjukkan, 11) Penerbitan dan percetakan, 12) Layanan komputer dan piranti lunak, 13) Televisi dan radio, 14) Riset dan pengembangan, dan 15) Kuliner. Kerajinan merupakan bagian dari seni kriya. Sifat produk seni kerajinan umumnya indah, menyenangkan, mudah dipahami, harga terjangkau, unik, mencerminkan budaya lokal, hasil kreativitas dengan ketrampilan tinggi (Astiti, N. K. A., 2014). Industri kecil subsector kerajinan adalah kegiatan kreatif yang berkaitan dengan kreasi, produk, dan distribusi produk yang dibuat dan dihasilkan oleh pelaku usaha atau tenaga perajin yang berawal dari desain awal sampai dengan proses penyelesaian produknya.

\section{Penelitian Terdahulu yang Berkaitan}

Faktor-faktor yang mempengaruhi eksistensi produk kriya yang memotivasi dalam proses produksi hasil penelitian Gerya, I M. (2014) adalah factor: individu, pendidikan, teknologi informasi, pariwisata, dan pemasaran. Dampak dan makna pada produk yang dihasilkannya yaitu dampak: ekonomi, pendidikan, sosial budaya, dan makna: simbolis, estetika, kesejahteraan, refleksi. Penelitian yang dilakukan oleh Sudana, I W., (2014) tentang pentingnya revital isasi cara pengolahan bahan baku, ketrampilan teknik produksi, dan kualitas hasil produksi kerajinan gerabah Gorontalo adalah melalui penerapan sinergi tiga konsep revitalisasi, yaitu: revitalisasi pengolahan bahan baku, revitalisasi teknik produksi, dan revitalisasi hasil produksi.

Penelitian yang dilakukan oleh Agustina, $\mathrm{R}$, \& Ahmar, N. (2014) tentang real earning manage ment dengan pendekatan biaya produksi analisis berdasarkan sektor industri pada perusahaan manufaktur, menghasilkan bahwa 125 atau $25 \%$ perusahaan yang termasuk 19 sektor industry yang tidak terindikasi melakukan manajemen laba riil dengan pendekatan biaya produksi, dan sisanya 377 atau $75 \%$ perusahaan-perusahaan yang termasuk 19 sektor industry cenderung terindikasi melakukan manajemen laba riil dengan pendekatan biaya produksi yang berada di skor satu dan empat. Trisnawati, et. al. (2012) menguji tentang pengukuran manajemen laba dengan pendekatan terintegrasi, pemilihan sampel dengan purposive sampling, alat uji dengan menggunakan uji regresi, uji beda, dan uji t. Hasil penelitian menunjukkan bahwa pada indeks LQ45 praktek manajemen laba memiliki pola bervariasi.

A rmando \& Farahmita (2012) menguji tentang manajemen laba riil melalui akrual dan aktivitas riil di sekitar penawaran sahamtambahan dan pengaruhnya terhadap kinerja perusahaan. Hasil penelitian menunjukkan bahwa perusahaan yang memiliki biaya perusahaan abnormal positif pada saat pelaksanaan SEO mengalami penurunan kinerja satu tahun pasca SEO. Hasil uji hipotesis biaya produksi abnormal sebelum SEO secara signifikan lebih tinggi dibandingkan biaya produksi abnormal setelah SEO. Arifin, et. el. (2012) menguji perbedaan kecenderungan pengungkapan corporate social responsibility (CSR): pengujian terhadap manipulasi akrual dan manipulasi riil. Hasil penelitian menunjukkan bahwa semakin rendah maupun semakin tinggi manipulasi laba riil dengan biaya produksi abnormal yang dilakukan, maka tidak akan mempengaruhi pengungkapan tanggung jawab sosial perusahaan. 


\section{Jurnal Keuangan dan Perbankan | KEUANGAN}

Vol. 19, N o.3, September 2015: 378-390

Penelitian yang dilakukan sekarang ini berbeda dengan penelitian sebelumnya. Perbedaannya menyangkut: lokasi penelitian dilakukan di UPT PSTKP Bali, obyek penelitian yang diuji adalah produk industri kreatif keramik (earthenware, stoneware, massa cor, glasir, dan prototipe) yang masing-masing diambil 3 (tiga) jenis komposisi, analisisuji berkaitan dengan rasio keuangan (likuiditas, profitabilitas, solvabilitas, aktivitas, dan penilaian) sebelum dan sesudah manajemen laba, manajemen laba yang dilakukan adalah biaya produksi khusus biaya overhead pabrik tetap, dan waktu penelitian diadakan tahun 2015.

\section{METODE}

Metode yang digunakan dalam analisis penelitian produk kreatif keramik (earthenware, stoneware, massa cor, glasir, dan prototipe) ini adalah: (1) Mengidentifikasi proses produksi produk kreatif keramik (earthenware, stoneware, massa cor, glasir, dan prototipe) dan mengumpulkan biaya produksi yang menjadi dasar perhitungan rasio keuangan (likuiditas, profitabilitas, solvabilitas, aktivitas, dan penilaian) sebelum adanya manajemen laba; (2) M elakukan manajemen laba dengan metode yang ketiga, yaitu produksi berlebihan untuk memperoleh biaya tetap satuan lebih rendah, sehingga biaya produksi satuan lebih rendah, dan akhirnya laba yang diperoleh lebih tinggi; (3) Mengidentifikasi proses produksi produk kreatif keramik (earthenware, stoneware, massa cor, glasir, dan prototipe) dan mengumpulkan biaya produksi yang menjadi dasar perhitungan rasio keuangan (likuiditas, profitabilitas, solvabilitas, aktivitas, dan nilai pasar) setelah adanya manajemen laba; dan (4) Membandingkan rasio keuangan sebelum dan setel ah adanya manajemen laba atas produk kreatif keramik, dan menghitung perubahan yang terjadi atas rasio keuangan sebagai akibat adanya manajemen laba; dan (5) Pengambilan keputusan sesuai dengan perumusan masalah, dan keterkaitannya dengan manajemen keuangan.
Teknik analisis data: 1) Sistem biaya standar dengan pendekatan biaya penuh digunakan untuk menghitung biaya produksi. Biaya produksi terdiri dari (Supriyono, 2014): biaya bahan baku + biaya tenaga kerja langsung + biaya overhead pabrik (tetap dan variabel); 2) Rasio likuiditas berkaitan Quick Ratio (QR) atau A cid Test Ratio (ACR), yaitu $\mathrm{QR}=(($ A ktiva Lancar - Persediaan): (Passiva Lancar)) $\times 100 \%$, rasio profitabilitas berkaitan dengan Profit $M$ argin (PM ), yaitu $P M=((L a b a$ Bersih): (Penjualan)) $\times 100 \%$, rasio solvabilitas berkaitan dengan Times Interest E arned (TIE), yaitu TIE = Laba Operasi: Biaya Bunga, rasio aktivitas berkaitan dengan Inventory Turnover (IT), yaitu IT = Harga Pokok Penjualan: Persediaan Rata-rata, dan rasio Penilaian yang berkaitan dengan Earning Per Share (EPS), yaitu EPS = EAT: Jumlah Lembar Saham, digunakan untuk menghitung rasio keuangan (Wiagustini, 2014) produk kreatif keramik sebelum dan setelah adanya manajemen laba; (3) Kegiatan memproduksi lebih banyak daripada yang diperlukan dengan asumsi bahwa tingkat produksi yang lebih tinggi akan menyebabkan biaya overhead tetap per unit produk lebih rendah (menurunkan kas barang terjual/ cost of goods sold) digunakan untuk melakukan manajemen laba (Ratmono dalamA gustina, 2014); dan (4) Trend atau tendensi posisi dan kemajuan keuangan perusahaan yang dinyatakan dalam prosentase (trend percentage analysis) untuk mengetahui tendensi keadaan keuangan, apakah menunjukkan tendensi tetap, naik atau bahkan turun (Kasmir, 2014:70) dari kelima produk kreatif keramik.

\section{HASIL PENEUTIAN}

\section{Rasio Keuangan Produk Kreatif Keramik Sebelum Adanya Manajemen Laba}

Rasio keuangan produk kreatif keramik yang terdiri dari limajenis produk (masing-masing 3 buah komposisi) sebelum adanya manajemen laba ditunjukkan pada Tabel 2: 


\section{Pengaruh M anajemen Laba terhadap Rasio Keuangan Produk Industri Kreatif Keramik}

I N yoman $\mathrm{N}$ ormal

Tabel 2 menunjukkan rasio keuangan produk industry kreatif keramik dengan mengambil lima jenis produk masing-masing tiga komposisi dan lima jenis rasio keuangan. Quick Ratio ( $Q R)$ dari: a) earthenware (BJN -2, TR-1, dan SGR-1) adalah 212\%, $204 \%$, dan $213 \%$, dengan rata-rata $209,67 \%$, b) stoneware (B2-B, BL-1X, dan BSK-2) adalah 210\%, $216 \%$, dan $212 \%$, dengan rata-rata $212,67 \%$, c) massa cor ( $\mathrm{CN}-7, \mathrm{CN}-6$, dan $\mathrm{CN}-1)$ adalah $166 \%$, $183 \%$, dan $186 \%$, dengan rata-rata $178,33 \%$, d) glasir (GHK-3, GMR-1, dan GK-1) adalah 179\%, $178 \%$, dan $179 \%$, dengan rata-rata $178,67 \%$, dan e) prototipe (cangkir hijau, teko coklat, dan piring ceper) adalah $248 \%$, $247 \%$, dan $246 \%$, dengan ratarata $247 \%$. Profit $M$ argin (PM) dari: a) earthenware (B) N - 2, TR - 1, dan SGR-1) adalah 14,50\%, 12,76\% dan $11,52 \%$, dengan rata-rata $12,93 \%$, b) stoneware (B2B, BL-1X, dan BSK-2) adalah 11,13\%, 12,12\%, dan $13,20 \%$, dengan rata-rata $12,15 \%$, c) massa cor (CN-7, CN-6, dan CN-1) adalah 12,06\%, 11,89\%, dan $10,85 \%$, dengan rata-rata $11,60 \%$, d) glasir
(GHK-3, GMR-1, dan GK-1) adalah 11,13\%, $11,31 \%$, dan $11,17 \%$, dengan rata-rata $11,20 \%$, dan e) prototipe (cangkir hijau, teko coklat, dan piring ceper) adalah $11,30 \%, 10,93 \%$, dan $12,34 \%$, dengan rata-rata 11,52\%. Time Interest Earned (TIE) dari: a) earthenware (BJN-2, TR-1, dan SG R-1) adalah 704\%, $626 \%$, dan $573 \%$, dengan rata-rata $634,33 \%$, b) stoneware (B2-B, BL-1X, dan BSK-2) adalah 556\%, $559 \%$, dan 646 , dengan rata-rata 587\%, c) massa cor (CN-7, CN-6, dan CN-1) adalah 696\%, 589\%, dan $545 \%$, dengan rata-rata $581 \%$, d) glasir (GHK3, GMR-1, dan GK-1) adalah 556\%, 564\%, dan $558 \%$, dengan rata-rata $559,33 \%$, dan e) prototipe (cangkir hijau, teko coklat, dan piring ceper) adalah $561 \%$, 557\%, dan $608 \%$, dengan rata-rata $575,33 \%$. Inventory Turnover (IT) dari: a) earthenware (BJN -2, TR-1, dan SG R-1) adalah 8,00 kali untuk BJN-2, TR1 , dan SGR-1, dengan rata-rata $8,00 \mathrm{kali} \%$, b) stoneware (B2-B, BL-1X, dan BSK-2) 11,33 kali untuk B2$\mathrm{B}, \mathrm{BL}-1 \mathrm{X}$, dan BSK-2, dengan rata-rata 11,33 kali, C) massa cor (CN-7, CN-6, dan $\mathrm{CN}-1)$ adalah 9,76

Tabel 2: Rasio Keuangan Produk Industri Kreatif Keramik Sebelum Adanya M anajemen Laba

\begin{tabular}{|c|c|c|c|c|c|c|}
\hline \multirow{3}{*}{\multicolumn{2}{|c|}{$\begin{array}{l}\text { Produk Kreatif } \\
\text { Keramik }\end{array}$}} & \multicolumn{4}{|c|}{ Rasio Keuangan } & \multirow{3}{*}{$\begin{array}{l}\text { Earning Per } \\
\text { Share(EPS) }\end{array}$} \\
\hline & & \multirow{2}{*}{$\frac{\text { Quick Ratio }}{\text { (QR) }}$} & \multirow{2}{*}{$\begin{array}{c}\text { Profit Margin } \\
\text { (PM) }\end{array}$} & \multirow{2}{*}{$\begin{array}{l}\text { Time Interest } \\
\text { Earned (TIE) }\end{array}$} & \multirow{2}{*}{$\begin{array}{c}\text { Inventory } \\
\text { Turnover (IT) }\end{array}$} & \\
\hline & & & & & & \\
\hline & 1 & 2 & 3 & 4 & 5 & 6 \\
\hline & $\mathrm{BJN}-2$ & 2,12 & 14,50 & 7,04 & 8,00 & $3.448,05$ \\
\hline \multirow{3}{*}{ Earthenware } & TR-1 & 2.04 & 12,76 & 6,26 & 8,00 & $3.596,93$ \\
\hline & SGR-1 & 2,13 & 11,52 & 5,73 & 8,00 & $2.573,33$ \\
\hline & B2-B & 2,10 & 11,13 & 5,56 & 11,33 & $3.693,13$ \\
\hline \multirow{3}{*}{ Stoneware } & $B L-1 X$ & 2,16 & 12,12 & 5,59 & 11,33 & $3.193,41$ \\
\hline & BSK-2 & 2,12 & 13,20 & 6,46 & 11,33 & $4.253,04$ \\
\hline & $\mathrm{CN}-7$ & 1,66 & 12,06 & 5,96 & 9,76 & $14.777,75$ \\
\hline \multirow[t]{3}{*}{ Massa Cor } & CN-6 & 1,83 & 11,89 & 5,89 & 9,76 & $14.748,77$ \\
\hline & $\mathrm{CN}-1$ & 1,86 & 10,85 & 5,45 & 9,76 & $12.642,83$ \\
\hline & GHK-3 & 1,79 & 11,13 & 5,56 & 13,38 & 298,50 \\
\hline \multirow[t]{3}{*}{ Glasir } & GMR-1 & 1,78 & 11,31 & 5,64 & 13,38 & 310,25 \\
\hline & GK-1 & 1,79 & 11,17 & 5,58 & 13,38 & 303,66 \\
\hline & Cangkir Hijau & 2,48 & 11,30 & 5,61 & 18,00 & 183,68 \\
\hline \multirow{2}{*}{ Prototipe } & Teko Coklat & 2,47 & 10,93 & 5,57 & 18,00 & 268,63 \\
\hline & Piring Ceper & 2,46 & 12,34 & 6,08 & 18,00 & 340,01 \\
\hline
\end{tabular}

Sumber: Hasil Pengolahan Data, 2015. 


\section{Jurnal Keuangan dan Perbankan | KEUANGAN}

Vol. 19, N o.3, September 2015: 378-390

kali, dengan rata-rata 9,76 kali, d) glasir (GHK-3, GM R-1, dan GK-1) adalah 13,38 kali, dengan ratarata 13,38 kali, dan e) prototipe (cangkir hijau, teko coklat, dan piring ceper) adalah 18,00 kali, dengan rata-rata 18,00 kali. Earning Peer Share (EPS) dari: a) earthenware (BJN -2, TR-1, dan SGR-1) Rp 3.448,05, $\mathrm{Rp}$ 3.596,93, dan $\mathrm{Rp} 2.573,33$, dengan rata-rata $\mathrm{Rp}$ 3.206,10, b) stoneware (B2-B, BL-1X, dan BSK-2) Rp 3.693,13, Rp 3.193,41, dan Rp 4.253,04, dengan ratarata $\mathrm{Rp} 3.713,19, \mathrm{c})$ massa cor $(\mathrm{CN}-7, \mathrm{CN}-6$, dan CN-1) adalah Rp 14.777,75, Rp 14.748,77, dan Rp 12.642,83, dengan rata-rata Rp 14.056,45, d) glasir (GHK-3, GMR-1, dan GK-1) adalah Rp 298,50, Rp 310,25, dan $\mathrm{Rp} 303,66$, dengan rata-rata $\mathrm{Rp} 304,14$, dan e) prototipe (cangkir hijau, teko coklat, dan piring ceper) adalah $\mathrm{Rp} 183,68, \mathrm{Rp} 268,63$, dan Rp 340,01, dengan rata-rata $\mathrm{Rp} 264,11$.

\section{Proses Manajemen Laba Produk Kreatif Keramik}

Proses manajemen laba produk kreatif keramik dilakukan dengan melakukan produksi berlebih sebesar 20\% dari kondisi normal. Produksi berlebih dari kondisi normal mengakibatkan terjadinya pengurangan biaya tetap terutama biaya overhead pabrik sebagai unsur dari biaya produksi dan penambahan persediaan akhir periode yang bersangkutan. Jumlah produksi, persediaan akhir, dan biaya tetap satuan pada proses manajemen laba ditunjukkan pada Tabel 3.

Tabel 3menunjukkan bahwa proses manajemen laba dilakukan dengan produksi berlebih sebanyak $20 \%$ untuk setiap jenis produk kreatif keramik, yaitu earthenware, stoneware, massa cor, glasir, dan prototipe. Kelebihan produksi sebesar $20 \%$ menghasilkan biaya overhead pabrik tetap sebesar Rp 339,63 per kg untuk BJN-2, Rp 339,63 per kg untuk TR-1, Rp 416,48 per kg untuk SGR-1, Rp 346,29 per kg untuk B2-B, Rp 416,48 per kg untuk BL-1X, Rp 346,29 per kg untuk BSK-2, Rp 30,08 per liter untuk CN-7, Rp 30,84 per liter untuk CN6, Rp 30,84 per liter untuk CN-1, Rp 4.444,71 per liter untuk GHK-3, Rp 4.321,01 per liter untuk GM R-1, Rp 4.321,01 per liter untuk GK-1, Rp 525,21 per buah untuk cangkir hijau, Rp 2.481,22 per buah

Tabel 3: Jumlah Produksi Normal, Produksi Berlebih, Persediaan Akhir, dan Biaya Overhead Pabrik Tetap Produk Industri Kreatif Keramik Pada Proses M anajemen Laba

\begin{tabular}{|c|c|c|c|c|c|c|}
\hline \multirow{2}{*}{\multicolumn{2}{|c|}{$\begin{array}{c}\text { Produk Kreatif } \\
\text { Keramik }\end{array}$}} & \multicolumn{4}{|c|}{ Uraian } & \multirow{3}{*}{$\begin{array}{c}\text { Penurunan } \\
\text { BO PT }\end{array}$} \\
\hline & & \multirow{2}{*}{$\begin{array}{c}\text { Jumlah } \\
\text { Produksi } \\
\text { Normal }\end{array}$} & \multirow{2}{*}{$\begin{array}{c}\text { Jumlah } \\
\text { Produksi } \\
\text { Berlebih }\end{array}$} & \multirow[t]{2}{*}{$\begin{array}{c}\text { Persediaan } \\
\text { Akhir }\end{array}$} & \multirow{2}{*}{$\begin{array}{c}\text { Biaya } \\
\text { Overhead } \\
\text { Pabrik Tetap } \\
\text { (BOPT) } \\
\end{array}$} & \\
\hline & & & & & & \\
\hline & $\mathrm{BJN}-2(\mathrm{~kg})$ & 16.515 & 19.818 & 6.606 & 339,63 & $12,79 \%$ \\
\hline \multirow[t]{3}{*}{ Earthenware } & TR-1 (kg) & 15.792 & 18.950 & 6.316 & 339,63 & $16,67 \%$ \\
\hline & SGR-1 (kg) & 14.100 & 16.920 & 5.640 & 416,48 & $16,67 \%$ \\
\hline & B2-B (kg) & 15.488 & 18.586 & 5.421 & 346,29 & $16,67 \%$ \\
\hline \multirow[t]{3}{*}{ Stoneware } & $\mathrm{BL}-1 \mathrm{X}(\mathrm{kg})$ & 14.100 & 16.920 & 4.935 & 416,48 & $16,67 \%$ \\
\hline & BSK-2 (kg) & 15.488 & 18.586 & 5.421 & 346,29 & $16,67 \%$ \\
\hline & $\mathrm{CN}-7(\mathrm{It})$ & 50.000 & 60.000 & 18.500 & 30,08 & $16,65 \%$ \\
\hline \multirow[t]{3}{*}{ Massa Cor } & $\mathrm{CN}-6(\mathrm{It})$ & 50.000 & 60.000 & 18.500 & 30,84 & $16,67 \%$ \\
\hline & $\mathrm{CN}-1$ (It) & 50.000 & 60.000 & 18.500 & 30,84 & $16,67 \%$ \\
\hline & GHK-3 (It) & 66,66 & 79,99 & 22,00 & $4.444,71$ & $16,67 \%$ \\
\hline \multirow[t]{3}{*}{ Glasir } & GMR-1 (It) & 68,57 & 82,28 & 22,62 & $4.321,01$ & $16,67 \%$ \\
\hline & GK-1 (It) & 68,57 & 82,28 & 22,62 & $4.321,01$ & $16,67 \%$ \\
\hline & Cangkir Hijau (bh) & 60 & 72 & 18 & 525,21 & $16,67 \%$ \\
\hline \multirow[t]{2}{*}{ Prototipe } & Teko Coklat (bh) & 22 & 26 & 6 & $2.481,22$ & $16,67 \%$ \\
\hline & Piring Ceper (bh) & 59 & 71 & 18 & $1.218,68$ & $16,67 \%$ \\
\hline
\end{tabular}

Sumber: Hasil Pengolahan Data, 2015. 


\section{Pengaruh M anajemen Laba terhadap Rasio Keuangan Produk Industri Kreatif Keramik}

I Nyoman N ormal

untuk teko coklat, dan Rp 1.218,68 per buah untuk piring ceper. Rata-rata penurunan biaya overhead pabrik produk kreatif keramik dengan adanya manajemen laba adalah 16,67\%.

\section{Rasio Keuangan Produk Kreatif Keramik Setelah Adanya Manajemen Laba}

Rasio keuangan produk kreatif keramik yang terdiri dari limajenis produk (masing-masing 3 buah komposisi ) setelah adanya manajemen laba ditunjukkan pada Tabel 4:

Tabel 4menunjukkan rasio keuangan produk industry kreatif keramik setelah adanya manajemen laba dengan mengambil lima jenis produk masing-masing tiga komposisi dan lima jenis rasio keuangan. Q uick Ratio (QR) dari: a) earthenware (BJ N-2, TR-1, dan SGR-1) adalah 225\%, 205\%, dan $215 \%$, dengan rata-rata $215 \%$, b) stoneware (B2-B, BL-1X, dan BSK-2) adalah 211\%, 217\%, dan 213\%, dengan rata-rata $213,67 \%, \mathrm{c})$ massa cor (CN-7, CN6 , dan $\mathrm{CN}-1$ ) adalah $167 \%$, 183\%, dan $187 \%$, dengan rata-rata 179\%, d) glasir (GHK-3, GMR-1, dan GK-1) adalah $181 \%$, 180\%, dan $181 \%$, dengan rata-rata $180,67 \%$, dan e) prototipe (cangkir hijau, teko coklat, dan piring ceper) adalah 248\%, 247\%, dan $247 \%$, dengan rata-rata $247,33 \%$. Profit M argin (PM ) dari: a) earthenware (BJ N -2, TR-1, dan SG R1) adalah $16,89 \%, 15,41 \%$, dan $15,16 \%$, dengan rata-rata $15,82 \%$, b) stoneware (B2-B, BL-1X, dan BSK-2) adalah 13,51\%, 14,24\%, dan 15,64\% , dengan rata-rata $14,46 \%, \mathrm{c})$ massa cor $(\mathrm{CN}-7, \mathrm{CN}-6$, dan $\mathrm{CN}-1$ ) adalah $12,24 \%, 12,07 \%$, dan $11,04 \%$, dengan rata-rata 11,78\%, d) glasir (GHK-3, GMR-1, dan GK-1) adalah $12,80 \%, 12,94 \%$, dan $12,82 \%$, dengan rata-rata $12,85 \%$, dan e) prototipe (cangkir hijau, teko coklat, dan piring ceper) adalah $11,54 \%$, $11,50 \%$, dan $12,75 \%$, dengan rata-rata $11,93 \%$. Time Interest Earned (TIE) dari: a) earthen ware (BJN -2, TR1, dan SGR-1) adalah 8,16 kali, 7,45 kali, dan 7,34 kali, dengan rata-rata 7,65 kali, b stoneware (B2-B, BL-1X, dan BSK-2) adalah 6,59 kali, 6,93 kali, dan 7,57 kali untuk BSK-2, dengan rata-rata 7,03 kali, c) massa cor ( $\mathrm{CN}-7, \mathrm{CN}-6$, dan $\mathrm{CN}-1)$ adalah 6,04

Tabel 4: Rasio Keuangan Produk Industri Kreatif Keramik Setelah Adanya M anajemen Laba

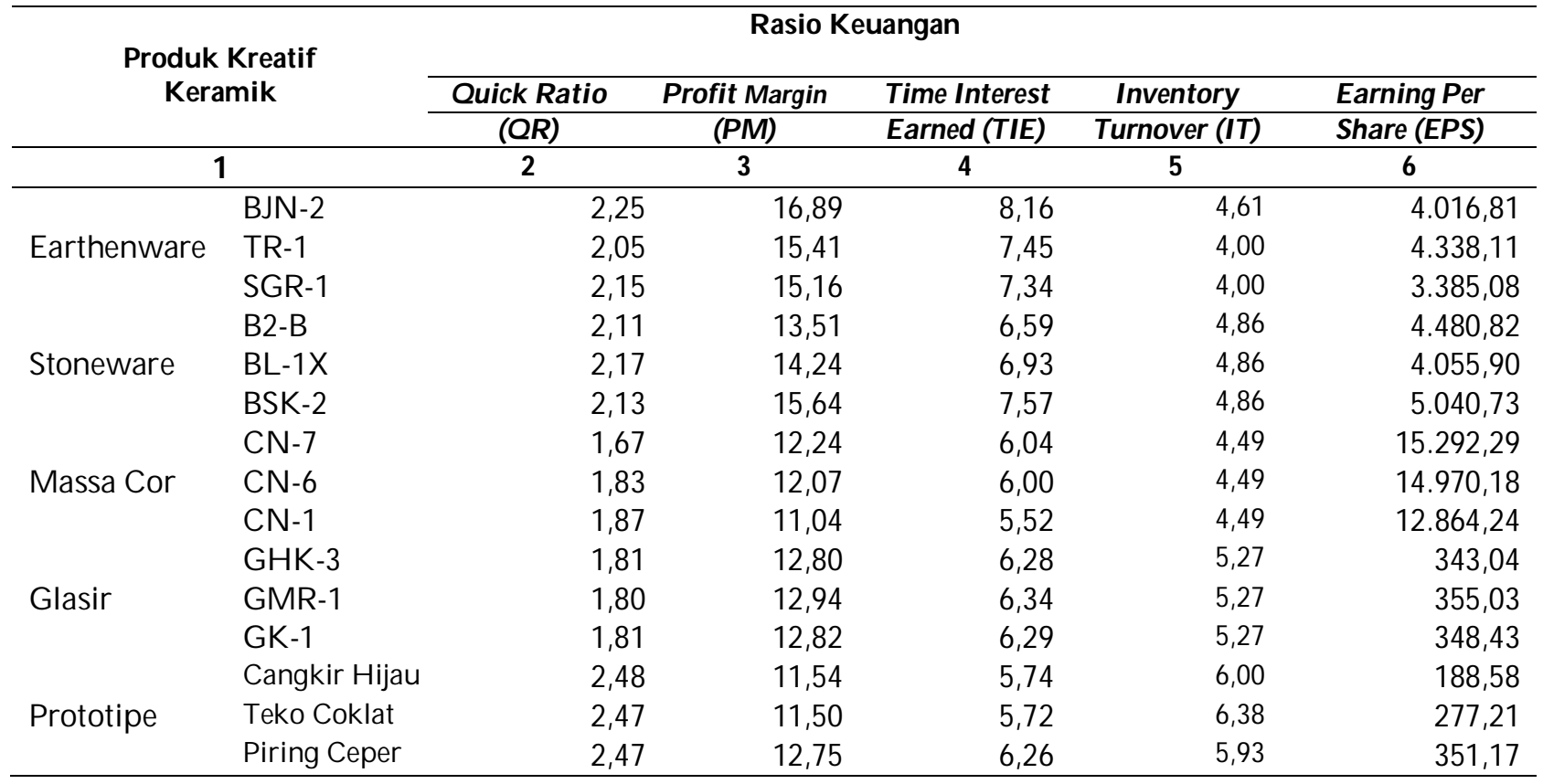




\section{Jurnal Keuangan dan Perbankan | KEUANGAN}

Vol. 19, N o.3, September 2015: 378-390

kali, 6,00 kali, dan 5,52 kali, dengan rata-rata 5,85 kali, d) glasir (GHK-3, GMR-1, dan GK-1) adalah 6,28 kali, 6,34 kali, dan 6,29 kali, dengan rata-rata 6,30 kali, dan e) prototipe (cangkir hijau, teko coklat, dan piring ceper) adalah 5,74 kali, 5,72 kali, dan 6,26 kali, dengan rata-rata 5,90 kali. Inventory Turnover (IT) dari: a) earthen ware (BJN -2, TR -1, dan SGR-1) adalah 4,61 kali, 4,00 kali, dan 4,00 kali, dengan rata-rata 4,20 kali, b stoneware (B2-B, BL1X, dan BSK-2) adalah 4,86 kali, dengan rata-rata 4,86 kali, c) massa cor (CN-7, CN-6, dan CN-1) adalah 4,49 kali, dengan rata-rata 4,49 kali, d) glasir (GHK-3, GMR-1, dan GK-1) adalah 5,27 kali, dengan rata-rata 5,27 kali, dan e) prototipe (cangkir hijau, teko coklat, dan piring ceper) adalah 6,00 kali, 6,38 kali, dan 5,93 kali, dengan rata-rata 6,10 kali. Earning Peer Share (EPS) dari: a) earthenware (BJN -2, TR-1, dan SGR-1) adalah Rp 4.016,81, $\mathrm{Rp}$ 4.338,11, dan $\mathrm{Rp} 3.385,08$, dengan rata-rata $\mathrm{Rp}$ 3.913,33, b) stoneware (B2-B, BL-1X, dan BSK-2) adalah Rp 4.480,82, Rp 4.055,90, dan Rp 5.040,73, dengan rata-rata Rp 4.525,82, c) massa cor (CN-7, CN -6, dan CN-1) adalah Rp 15.292,29, Rp 14.970,18, dan $\mathrm{Rp} 12.864,24$, dengan rata-rata $\mathrm{Rp}$ 14.375,57, d) glasir (GHK-3, GMR-1, dan GK-1) adalah Rp 343,04, Rp 355,03, dan $\mathrm{Rp} 348,43$, dengan rata-rata Rp 348,83, dan e) prototipe (cangkir hijau, teko coklat, dan piring ceper) adalah Rp 188,58, Rp 277,21, dan Rp 351,17, dengan rata-rata Rp 272,32.

\section{PEMBAHASAN}

\section{Rasio Likuiditas (Quick Ratio) Produk Industri Kreatif Keramik}

Rata-rata rasio likuiditas yang diwakili oleh rasio cepat (quick ratio) earthenware, stoneware, massa cor, glasir, dan prototipe adalah 209,67\%, $212,67 \%, 178,33 \%, 178,67 \%$, dan $247,00 \%$, yang menunjukkan bahwa dari Rp 100,00 utang lancar yang dimiliki maka tersedia $R p$ 209,67, Rp 212,67, Rp 178,33, Rp 178,67, dan Rp 247,00, aktiva lancar selain persediaan yang akan digunakan untuk melunasinya. Proses manajemen laba dilakukan dengan melakukan produksi berlebih earthenware, stoneware, massa cor, glasir, dan prototipe sebesar $20 \%$ dari kondisi normal dengan tujuan untuk menurunkan biaya overhead pabrik tetap (rata-rata 16,67\%) dan menambah persediaan akhir (rata-rata 20\%). Rata-rata rasio cepat (quick ratio) earthenware, stoneware, massa cor, glasir, dan prototipe setelah dilakukan manajemen laba adalah $215,00 \%$, 213,67\%, $179,00 \%$, $180,67 \%$, dan $247,33 \%$ menunjukkan bahwa dari Rp 100,00 utang lancar yang dimiliki maka tersedia Rp 215,00, Rp 213,67, Rp 179,00, Rp 180,67, dan Rp 247,33 aktiva lancar selain persediaan yang akan digunakan untuk melunasinya. Proses manajemen laba dapat memberikan informasi kepada pihak terkait tentang peningkatan kinerja keuangan manajer atau pimpinan khususnya quick ratio earthen ware, stoneware, massa cor, glasir, dan prototipe sebesar $5,33 \%$, $1,00 \%, 0,67 \%, 2,00 \%$, dan $0,33 \%$.

\section{Rasio Profitabilitas (Profit Margin) Produk Industri Kreatif Keramik}

Rata-rata rasio profitabilitas yang diwakili oleh marjin laba (profit margin) earthenware, stoneware, massa cor, glasir, dan prototipe adalah $12,93 \%, 12,15 \%$, $11,60 \%$, 11,20\%, dan $11,52 \%$. Rasio ini menunjukkan bahwa kemampuan perusahaan atau organisasi untuk memperoleh laba atau keuntungan bersih sebelum pajak (EBIT) dibandingkan penjualan yang dilakukan pada periode tersebut. Hasil yang diperoleh untuk produk kreatif keramik adalah bernbeda untuk masing-masing jenis produk. Dengan kata lain tersedia $12,93 \%$, $12,15 \%, 11,60 \%, 11,20 \%$, dan $11,52 \%$ laba atau keuntungan bersih sebelum pajak dari $100 \%$ jumlah penjualan yang terjadi pada perusahaan atau organisasi dari masing-masing jenis produk industri kreatif keramik. Rata-rata marjin laba (profit margin) earthenware, stoneware, massa cor, glasir, dan prototipe setelah dilakukan manajemen laba 


\section{Pengaruh Manajemen Laba terhadap Rasio Keuangan Produk Industri Kreatif Keramik}

I $\mathrm{N}$ yoman $\mathrm{N}$ ormal

adalah $15,82 \%, 14,46 \%, 11,78 \%, 12,85 \%$, dan $11,93 \%$ menunjukkan bahwa dari 100,00\% jumlah penjualan yang terjadi dalam satu periode, maka tersedia 15,82\%, 14,46\%, 11,78\%, 12,85\%, dan $11,93 \%$ laba atau keuntungan bersih sebelum pajak yang akan digunakan untuk menambah modal, dibagikan, atau investasi lainnya sesuai dengan kebijakan manajemen. Proses manajemen laba dapat memberikan informasi kepada pihak terkait tentang kemampuan perusahaan untuk mengatur dan merencanakan laba dalam usaha peningkatan kinerja keuangan manajer atau pimpinan khususnya marjin laba. Semakin tinggi profit marjin, makakemampuan perusahaan untuk menghasilkan laba bersih sebelum pajak semakin besar. $\mathrm{Hal}$ ini mencerminkan kinerja keuangan manajer atau pimpinan semakin baik. Kenaikan profit margin earthenware, stoneware, massa cor, glasir, dan prototipe pada industri kreatif keramik PSTKP Bali adalah: 2,89\%, 2,31\%, 0,18\%, 1,65\%, dan 0,41\%.

\section{Rasio Solvabilitas (Time Interest Earned) Produk Industri Kreatif Keramik}

Rata-rata rasio solvabilitas yang diwakili oleh laba sebelum bunga dan pajak terhadap beban bunga (Time Inter est Earned) earthenware, stoneware, massa cor, glasir, dan prototipe adalah 6,34 kali, 5,87 kali, 5,81 kali, 5,59 kali, dan 5,75 kali. Rasio ini menunjukkan bahwa kemampuan perusahaan atau organisasi untuk membayar beban bunga yang jatuh tempo dari tersedianya laba sebelum bunga dan pajak pada periodetersebut. H asil yang diperoleh untuk produk kreatif keramik adalah berbeda untuk masing-masing jenis produk. Dengan kata lain tersedia 6,34 kali, 5,87 kali, 5,81 kali, 5,59 kali, dan 5,75 kali laba atau keuntungan bersih sebelum bunga dan pajak dibandingkan beban bunga yang jatuh tempo yang terjadi pada perusahaan atau organisasi dari masing-masing jenis produk industri kreatif keramik. Rata-rata Time Interest Earned earthenware, stoneware, massa cor, glasir, dan prototipe setelah dilakukan manajemen laba adalah 7,65 kali, 7,03 kali, 5,83 kali, 6,30 kali, dan 5,90 kali, menunjukkan bahwa dari 100,00\% jumlah beban bunga yang jatuh tempo daIam satu periode, maka tersedia 7,65 kali, 7,03 kali, 5,83 kali, 6,30 kali, dan 5,90 kali laba atau keuntungan sebelum bunga dan pajak yang akan digunakan untuk melunasi atau membayarnya. Proses manajemen laba dapat memberikan informasi kepada pihak terkait tentang kemampuan perusahaan untuk membayar beban bunga yang jatuh tempo dari sejumlah laba sebelum bunga dan pajak dalam usaha peningkatan kinerja keuangan manajer atau pimpinan khususnyatimeinterest earned. Semakin tinggi time interest earned, maka kemampuan perusahaan untuk membayar beban bunga yang jatuh tempo dari laba sebelum bunga dan pajak semakin besar. Hal ini mencerminkan kinerja keuangan manajer atau pimpinan semakin baik. Kenaikan timeinterest earned earthenware, stoneware, massa cor, glasir, dan prototipe pada industri kreatif keramik PSTKP Bali adalah: 1,30 kali, 1,16 kali, 0,02 kali, 0,71 kali, dan 0,15 kali.

\section{Rasio Aktivitas (Activity Ratio) Produk Industri Kreatif Keramik}

Rata-rata rasio aktivitas yang diwakili oleh tingkat perputaran persediaan (Inventory Turnover) earthenware, stoneware, massa cor, glasir, dan prototipe adalah 8,00 kali, 11,33 kali, 9,76 kali, 13,38 kali, dan 18,00 kali. Rasio ini menunjukkan bahwa seberapa besar (kali) efisieansi penggunaan dana yang tertanam dalam persediaan dari suatu perusahaan atau organisasi dapat berputar menjadi kas pada satu periodeakuntansi. Hasil yang diperoleh untuk produk kreatif keramik adalah berbeda untuk masing-masing jenis produk. Dengan kata Iain terjadi 8,00 kali, 11,33 kali, 9,76 kali, 13,38 kali, dan 18,00 kali perputaran persediaan pada perusahaan atau organisasi dari masing-masing jenis produk industri kreatif keramik dalam satu periode. 


\section{Jurnal Keuangan dan Perbankan | KEUANGAN}

Vol. 19, N o.3, September 2015: 378-390

Rata-rata I nventory T urnover earthenware, stoneware, massa cor, glasir, dan prototipe setelah dilakukan manajemen laba adal ah 4,20 kali, 4,86 kali, 4,49 kali, 5,27 kali, dan 6,10 kali. Hal ni berarti persediaan yang dimiliki oleh perusahaan atau organisasi dapat berubah menjadi kas dalam rangka menciptaan laba sebanyak 4,20 kali, 4,86 kali, 4,49 kali, 5,27 kali, dan 6,10 kali. Proses manajemen laba dapat memberikan informasi kepada pihak terkait tentang seberapa besar kemampuan produk dari perusahaan untuk berputar atau berubah menjadi kas untuk menghasilkan laba bersih dalam usaha peningkatan kinerja keuangan manajer atau pimpinan khususnya persediaan. Semakin tinggi inventory turnover, berarti kemampuan produk dari suatu perusahaan untuk berubah menjadi kas dalam menghasilkan laba akan semakin besar. Hal ini mencerminkan kinerja keuangan manajer atau pimpinan semakin baik. Penurunan inventory turnover earthenware, stoneware, massa cor, glasir, dan prototipe pada industri kreatif keramik PSTKP Bali adalah: 3,80 kali, 6,47 kali, 5,27 kali, 8,11 kali, dan 11,90 kali. Proses manajemen laba dengan melakukan produksi berlebih di satu sisi memberikan efek positip, namun di sisi lain juga membawa efek negatip. Efek negatip timbul karena terjadinya penumpukkan persediaan akhir yang belum dapat dijual pada periode tersebut karena produksi di atas normal. N amun kondisi ini akan mengurangi risiko kekurangan atau kehabisan persediaan apabila ada pesanan mendadak yang berlebih.

\section{Rasio Penilaian (Valuation Ratio) Produk Industri Kreatif Keramik}

Rata-rata rasio penilaian yang diwakili oleh pendapatan per lembar saham (Earning Peer Share) earthenware, stoneware, massa cor, glasir, dan prototipe adalah Rp 3.206,10, Rp 3.713,19, Rp 14.056,45, Rp 304,14, dan Rp 264,11. Rasio ini menunjukkan pengakuan pasar terhadap kondisi keuangan yang dicapai perusahaan atau mengukur kemampuan manajemen dalam menciptakan nilai pasarnya diatas biaya investasi. Laba per lembar saham (Earning P eer Share) menunjukkan bahwa seberapa besar kemampuan perusahaan untuk menghasilkan laba bersih setelah pajak (EAT) jika dibandingkan dengan jumlah lembar saham yang beredar. Rata-rata pendapatan per lembar saham (E arning Peer Share) earthenware, stoneware, massa cor, glasir, dan prototipe setelah dilakukan manajemen laba adalah Rp 3.913,33, Rp 4.525,82, Rp 14.375,57, Rp 348,83, dan Rp 272,32. Hal ini berarti kemampuan perusahaan atau organisasi untuk menghasilkan laba jika dibandingkan dengan jumlah saham yang beredar menurut penilaian pasar adalah Rp 3.913,33, Rp 4.525,82, Rp 14.375,57, Rp 348,83, dan Rp 272,32. Proses manajemen laba dapat memberikan informasi kepada pihak terkait tentang seberapa besar kemampuan produk dari perusahaan untuk menghasilkan laba bersih dibandingkan jumlah lembar saham beredar dalam usaha peningkatan kinerja keuangan manajer atau pimpinan. Semakin tinggi pendapatan per lembar saham (Earning Peer Share), berarti kemampuan produk dari suatu perusahaan untuk menghasilkan laba setelah pajak akan semakin besar. $\mathrm{H}$ al ini mencerminkan kinerja keuangan manajer atau pimpinan semakin baik. Peningkatan pendapatan per lembar saham (Earning P er Share) earthen ware, stone ware, massa cor, glasir, dan prototipe pada industri kreatif keramik PSTKP Bali adalah: Rp 707,33, Rp 812,63, Rp 319,12, Rp 44,69, dan Rp 8,21. Proses manajemen laba dengan melakukan produksi berlebih di satu sisi memberikan efek positip, namun di sisi lain juga membawa efek negatip. Efek positip timbul karena terjadinya penurunan biaya overhead pabrik tetap satuan. Biaya overhead pabrik tetap turun berarti harga pokok produksi satuan juga turun. Dengan mengasumsikan bahwa harga jual, beban operasi, beban diluar usaha, pajak, dan jumlah lembar saham yang sama, maka akan didapat laba per lembar saham (Earning Peer Share) pada periode tersebut akan naik. 


\section{Pengaruh M anajemen Laba terhadap Rasio Keuangan Produk Industri Kreatif Keramik}

I $\mathrm{N}$ yoman $\mathrm{N}$ ormal

\section{SIMPULAN DAN SARAN}

\section{Simpulan}

Berdasarkan hasil dan pembahasan, maka dapat dibuatsimpulan: (1) Rasio keuangan produk industri kreatif keramik (earthenware, stoneware, massa cor, glasir, dan prototipe) jika dikaji berdasarkan lima rasio yang mewakili kelima aspek rasio keuangan (likuiditas, profitabilitas, solvabilitas, aktivitas, dan penilaian) sebelum manajemen laba adalah sebagai berikut: a) Rata-rata rasio cepat adalah 209,67\%, 212,67\%, 178,33\%, $178,67 \%$, dan $247,00 \%$, b) Rata-rata marjin laba adalah 12,93\%, 12,15\%, 11,60\%, 11,20\%, dan $11,52 \%$, c) Rata-rata rasio pendapatan terhadap beban bunga adalah 6,34 kali, 5,87 kali, 5,81 kali, 5,59 kali, dan 5,75 kali, d) Rata-rata tingkat perputaran persediaan adalah 8,00 kali, 11,33 kali, 9,76 kali, 13,38 kali, dan 18,00 kali, dan e) Rata-rata pendapatan per lembar saham adalah Rp 3.206,10, Rp 3.713,19, Rp 14.056,45, Rp 304,14, dan Rp 264,11. Rasio keuangan sebelum manajemen laba mencerminkan kondisi keuangan sesungguhnya yang terjadi pada periodetersebut, sehingga belum tampak adanya kesengajaan manajemen untuk mengatur rasio keuangan tersebut; (2) Manajemen laba merupakan tindakan manajer dengan menyajikan laporan yang menaikan (menurunkan) laba periode berjalan dari unit usaha yang menjadi tanggungjawabnya, tanpa menimbulkan kenaikan (penurunan) profitabilitas ekonomi unit tersebut dalam jangka panjang. Manajemen laba pada penelitian ini dilakukan dengan produksi berlebih sebesar $20 \%$. Produksi berlebih akan menurunkan biaya overhead pabrik tetap $16,67 \%$ dan menambah persediaan akhir $20 \%$. Penurunan biaya overhead pabrik tetap dapat menurunkan harga pokok produksi. Rata-rata harga pokok produksi produk industri kreatif keramik (earthenware, stoneware, massa cor, glasir, dan prototipe) setelah manajemen laba adalah: Rp 1.953,90 per kg, Rp 2.423,74 per kg, Rp 3.310,19 per liter, Rp 46.139,26 per liter, dan
Rp 68.971,27 per buah; dan (3) Rasio keuangan produk industri kreatif keramik (earthenware, stoneware, massa cor, glasir, dan prototipe) jika dikaji berdasarkan lima rasio yang mewakili kelima aspek rasio keuangan (likuiditas, profitabilitas, solvabilitas, aktivitas, dan penilaian) setelah manajemen laba adalah sebagai berikut: a) Ratarata rasio cepat adalah $215,00 \%, 213,67 \%, 179,00 \%$, $180,67 \%$, dan $247,33 \%$, b) Rata-rata marjin laba adalah 15,82\%, 14,46\%, 11,78\%, 12,85\%, dan $11,93 \%$, c) Rata-rata rasio pendapatan terhadap beban bunga adalah 7,65 kali, 7,03 kali, 5,83 kali, 6,30 kali, dan 5,90 kali, d) Rata-rata tingkat perputaran persediaan adalah 4,20 kali, 4,86 kali, 4,49 kali, 5,27 kali, dan 6,10 kali, dan e) Rata-rata pendapatan per lembar saham adalah Rp 3.913,33, Rp 4.525,82, Rp 14.375,57, Rp 348,83, dan Rp 272,32. Rasio keuangan setelah manajemen laba mencerminkan kondisi keuangan perusahaan atau organisasi yang terjadi pada periode tersebut setelah adanya pengaturan yang dilakukan oleh manajer, sehingga tampak adanya kesengajaan manajemen untuk mengatur rasio keuangan tersebut. Manajemen laba pada penelitian ini berpengaruh terhadap rasio keuangan produk industri kreatif keramik. Manajemen laba dapat menaikkan rasio keuangan produk industri kreatif keramik (earthenware, stoneware, massa cor, glasir, dan prototipe) terhadap aspek: a) Likuiditas (rasio cepat) sebesar 5,33\%, 1,00\%, 0,67\%, 2,00\%, dan 0,33\%, b) Profitabilitas (marjin laba) sebesar 2,89\%, 2,31\%, $0,18 \%, 1,65 \%$, dan $0,41 \%$, c) Solvabilitas (rasio laba operasi terhadap beban bunga) sebesar 1,31 kali, 1,16 kali, 0,02 kali, 0,71 kali, dan 0,15 kali, d) Penilaian (laba per lembar saham) sebesar Rp 707,23, Rp 812,63, Rp 319,12, Rp 44,69, dan Rp 8,21. Sebaliknya, manajemen laba dapat menurunkan aspek aktivitas (perputaran persediaan) produk industri kreatif keramik (earthenware, stoneware, massa cor, glasir, dan prototipe) sebesar 3,8 kali, 6,47 kali, 5,27 kali, 8,11 kali, dan 11,90 kali. 


\section{Jurnal Keuangan dan Perbankan | KEUANGAN}

Vol. 19, N o.3, September 2015: 378-390

\section{Saran}

Saran saya: (1) Kepada UPT PSTKP Bali, agar segera mempertimbangkan proses manajemen laba terhadap produksi dan penjualan produk industri kreatif keramik sehingga dapat meningkatkan rasio keuangan dan kinerja keuangan pada suatu periode akuntansi; (2) Kepada Perajin atau Pengusaha Keramik, agar meningkatkan manajemen keuangan unit bisnisnya, melalui manajemen laba terhadap produk-produk yang dihasilkan, sehingga sedikit demi sedikit akan terasa manfaat akuntansi dan manajemen keuangan dalam pengembangan usahanya dimasa yang akan datang; (3) Kepada Peneliti, Teknisi Litkayasa, Perekayasa, dan Kalangan Akademis Lain (Lanjutan), agar menerapkan konsep manajemen laba tidak hanya pada produk industri kreatif keramik, tetapi pada berbagai macam produk yang lebih spesifik, sehingga analisinya akan mencerminkan variasi dari produk-produk unggulan.

\section{DAFTAR PUSTAKA}

Agustina, R., \& Ahmar, N.. 2014. Real Earnings Management dengan Pendekatan Biaya Produksi, Analisis Berdasarkan Sektor Industri pada Perusahaan Manufaktur. Jurnal IImiah A kuntansi dan Humanika (JIN A H ), 3(2): 1172-1192.

A rifin, B., Janursi, Y., \& Ulfah, F.. 2012. Perbedaan Kecenderungan Pengungkapan Corporate Social Responsibility: Pengujian terhadap Manipulasi Akrual dan Manipulasi Riil. SN A XV , 1-29.

Arizona, I P. E.. 2014. Penerapan Activity-Based Costing (ABC) dalam Menentukan Harga Pokok Produk. JUARA (Jurnal Riset A kuntansi), 4(1): 78-85.

Armando, E., \& Farahmita, A... 2012. Manajemen Laba Melalui A krual dan A ktivitas Riil di Sekitar Penawaran Saham Tambahan dan Pengaruhnya terhadap Kinerja Perusahaan: Studi pada Perusahaan yang Terdaftar di Bursa Efek Indonesia Tahun 2001 - 2007. SN A XV Banjarmasin Kode AKPM 18, 1-30.

Astiti, N. K. A., 2014. Uang Kepeng Sepanjang Masa: Perspektif Arkeologi dan Ekonomi Kreatif di Provinsi Bali. Forum Arkeologi, 27(1): 45-56.
Gerya, I M... 2014. Eksistensi Produk Kriya Kayu Nyoman Sudarma di Desa Jagapati Kabupaten Badung dalam Dunia Bisnis. M UDRA (Jurnal Seni Budaya), 29(2):155-162.

Http:/ / semangadmu.blogspot.com/ 2013/ 11/ manajemen-laba-apakah-termasuk fraud.

Http:/ / id.wikipedia.org/ wiki/ Industri_kreatif).

Maryam, S.. 2013. Pertumbuhan Industri Manufaktur 2013 Ditarget 7,14\%. M edia Industri, 1.

Normal, I N.. 2013. Pengaruh Komposisi $\mathrm{Fe}_{2} \mathrm{O}_{3}$ dan $\mathrm{P}_{4} \mathrm{O}$ terhadap Karakteristik Fisik dan Variabel Keuangan yang Memjadi Dasar Pengambilan Keputusan Bisnis Glasir RUS pada UPT PSTKP Bali-BPPT. Jurnal Wacana Ekonomi, 11(1): 56-72.

Purwanto, dkk.. 2012. H ubungan A simetri Informasi dengan Tindakan M anajemen Laba sebagai Implikasi dari Hubungan Keagenan. Tugas A khir. Tegal. Program Studi Akuntansi, Fakultas Ekonomi, Universitas Pancasakti.

Rolita, R.. 2014. Hubungan Struktur Modal dan Keputusan Investasi pada Perusahaan Manufaktur. Jurnal Keuangan dan Perbankan, 18(3): 370-383.

Roychowdhury, S. 2006. Earnings M anagement Through Real Activities Manipulation. Journal of A ccounting and Economics, 335-370.

Rudianto. 2013. A kuntansi M anajemen (Informasi U ntuk Pengambilan K eputusan Strategis). Jakarta. Erlangga.

Sudana, I W.. 2014. Strategi Pengembangan Kerajinan Gerabah Tradisional Gorontalo Guna Mendukung Industri Kreatif. M U D RA (Jurnal Seni Budaya),29(2):163-180.

Supriyono, R.A. 2014. A kuntansi Biaya, Pengumpulan Biaya \& Penentuan $\mathrm{H}$ arga Pokok. Buku 1. Edisi 2. Cetakan Kedelapanbelas. Yogyakarta. BPFE.

Sutriasih, E., Putra, I G. C., \& Suryawathy, I G. A .. 2013. Pengaruh Informasi Laba Bersih, Arus Kas, dan Publikasi Dividen pada Volume Perdagangan Perusahaan Manufaktur di Bursa Efek Indonesia. Jurnal IImiah A kunatnsi dan Humanika (JINAH), 3(1):1055-1070.

Trisnawati, R., Wiyadi, \& Sasongko, N.. 2012. Pengukuran Manajemen Laba: Pendekatan Terintergrasi. SN A XV Banjarmasin AK PM 71, 1-40.

Wiagustini, Ni Luh Putu. 2014. M anajemen Keuangan. Cetakan Pertama. Denpasar. Udayana University Press. 